\title{
Un dios despedazado y disperso Imágenes de Jesús en la obra de Borges"
}

\author{
Lucas Adur \\ Universidad de Buenos Aires
}

\section{RESUMEN}

Desde sus primeros poemas expresionistas en los años veinte hasta el texto que abre Los conjurados (1985), la figura de Jesucristo es recurrente, o mejor aún, insistente en la obra borgeana. Tratada con ironía y distancia algunas veces, pero generalmente objeto de fascinación y un singular fervor agnóstico, Cristo aparece como una figura ineludible. Nos proponemos entonces rastrear los rostros de Jesús que pueden encontrarse "dispersos" en la obra de Borges. Nos concentraremos en tres figuras que consideramos las más relevantes. La primera es la del crucificado, una imagen que pone el énfasis en la humanidad de Cristo negando - o poniendo en suspenso al menos- su divinidad. La segunda es la del poeta, el mayor de los maestros orales, creador de espléndidas metáforas, objeto por tanto de una valoración estética y ética. La tercera, la del Verbo encarnado, el dios que se hace hombre. Como veremos, estas imágenes de Jesús pueden relacionarse, además, con ciertos núcleos de la poética borgeana.

Palabras clave: Borges, crucificado, maestro y poeta, Verbo encarnado

\footnotetext{
"Lucas Adur es Doctor en Letras por la Universidad de Buenos Aires y becario posdoctoral del Conicet. Profesor de Literatura Latinoamericana II y de Problemas de Literatura Latinoamericana en la Facultad de Filosofía y Letras de la Universidad de Buenos Aires. Se desempeña como editor en la revista El Ansia, dedicada a la literatura argentina contemporánea. Ha publicado artículos sobre la obra de Borges en diversas revistas especializadas.
}

https://doi.org/10.18800/lexis.201802.003 


\section{ABSTRACT}

From his first expressionist poems in the 1920 s to "Cristo en la cruz" (1985), the figure of Jesus Christ is recurrent in Borges' work. Sometimes treated with irony, but generally an object of fascination and singular agnostic fervor, Jesus appears as an inescapable figure. In this article I will analyze the representations of Jesus in Borges' work. I will focus on three images that I consider to be the most relevant ones. First, the Crucified, an image that emphasizes Christ's humanity by denying - or at least suspending - his divinity. Second, the poet, the greatest of the oral masters, creator of splendid metaphors, and the object of an aesthetic and ethical appreciation. And third, the Incarnate Word, the God who becomes man. As I will attempt to show, these images of Jesus can also be related to some core elements in Borges' poetics.

Keywords: Borges, crucified, master and poet, incarnate Word

En “Paradiso, XXXI, 108”, un texto breve publicado en Sur en 1954 -recogido luego en El Hacedor-, leemos:

Diodoro Sículo refiere la historia de un dios despedazado y disperso. ¿Quién, al andar por el crepúsculo o al trazar una fecha de su pasado, no sintió alguna vez que se había perdido una cosa infinita?

Los hombres han perdido una cara, una cara irrecuperable, y todos querrían ser aquel peregrino [...] que en Roma ve el sudario de la Verónica y murmura con fe: «Jesucristo, Dios mío, Dios verdadero ¿así era, pues, tu cara?» (OCII: 178). ${ }^{1}$

El rostro de Jesús se presenta, en este texto, como un rostro perdido, disperso entre una multiplicidad de imágenes. Irrecuperable, pero objeto de una búsqueda persistente, que parece involucrar a

\footnotetext{
Como es frecuente en la crítica borgeana, remitimos a las Obras completas y los Textos recobrados de acuerdo a las abreviaturas $O C$ y $T R$ respectivamente, tal como se indica en la bibliografía de este trabajo. Por lo tanto, las citas de los diversos textos del autor tendrán como referencias parentéticas el dato del volumen y las páginas correspondientes de las Obras Completas (OC) y de los Textos recobrados (TC). De esta manera, se prescindirá de los datos de autor y año - que se repondrán en el cuerpo del texto en los casos en que sea relevante- Para los textos de Borges no incluidos en OC ni en TR se utilizará el modo habitual de citación.
} 
todos los hombres, y que años después, en "Cristo en la cruz", uno de los últimos poemas publicados por Borges, el yo lírico asumirá en primera persona:

El rostro no es el rostro de las láminas.

Es áspero y judío. No lo veo

y seguiré buscándolo hasta el día

último de mis pasos en la tierra (OCIII: 453).

Hay, entonces, imágenes falsas, equivocadas —las que se multiplican en las láminas- y un rostro -áspero y judío- que no se ve, que es objeto de una "larga busca" (OCIII: 486) — como se afirma en otro poema del mismo libro-. Proponemos en este trabajo indagar cuáles son entre la pluralidad de "rostros" o imágenes de Jesús, dispersos en ese infinito texto que es la cultura occidental, aquellos que Borges ha privilegiado en su obra y de qué modo los ha elaborado en relación con su propia poética.

\section{Cuestiones preliminares}

Antes de detenernos en el examen de las tres imágenes de Jesús que consideramos las más significativas en la obra de Borges, conviene despejar dos cuestiones preliminares. En primer lugar, subrayar la importancia — cuantitativa y cualitativa- que tiene la figura de Cristo $^{2}$ en la producción borgeana, dado que, si bien se trata de una cuestión perceptible en la lectura de su obra, no ha sido suficientemente destacada por la crítica.

Desde sus primeros poemas expresionistas de los años veinte, hasta varios de los textos incluidos en Los conjurados - publicado en 1985-, 3 pasando por ensayos como "Vindicación del falso Basílides" o "Historia de la eternidad" y relatos como "Tres versiones

\footnotetext{
2 A lo largo de este trabajo utilizaremos indistintamente los términos "Cristo", "Jesús" y "Jesucristo". Si bien cada uno tiene sentidos específicos, Borges — hasta donde hemos podido constatar - los emplea indiscriminadamente, como si fueran equivalentes.

3 Con respecto a los poemas ultraístas, ver por ejemplo "Guardia Roja” (TRI: 91). En Los conjurados pueden encontrarse referencias explícitas a Cristo en "Cristo en la Cruz", “Doomsday”, “Alguien sueña” y “Otro fragmento apócrifo”.
} 
de Judas" o "El evangelio según Marcos”, Jesucristo es una figura recurrente, o mejor aún, insistente en la obra de Borges. Basta cotejar el Index confeccionado por el Borges Center para comprobar que pueden encontrarse referencias explícitas en más de 200 textos, atravesando todas las etapas de la producción del escritor. ${ }^{4}$ Se trata, además, de una figura que - fuera de algunas ironías dispersas en ciertos textos, no demasiado significativas $-{ }^{5}$ despierta un interés y una admiración superlativos: "el mayor de los maestros orales" (OCII: 92), "la figura más vívida de la memoria humana", la "que ha gobernado y sigue gobernando el curso de la historia" (OCIV: 480 ), cuyo discurso - tal como se lo registra en los evangelios"excede, acaso, la capacidad de la literatura" (Borges y Edelberg [1955] 1998:75).

La importancia de Jesús en la obra de Borges radica también en que su historia integra el elenco de las escasas "fábulas esenciales" —el término es de Lefere (1998:78) — que los hombres, a lo largo del tiempo, "han repetido siempre" (OCII:446) — según afirma el narrador de "El evangelio según Marcos" —. La historia de "un dios que se hace crucificar en el Gólgota", no solo ha sido recreada constantemente en el arte y en la literatura occidental - como se dice en la conferencia sobre "El arte de contar historias" (Borges 2000a:66) —, sino que funciona como un modelo hipotextual para la propia literatura de Borges. En efecto, de un modo muy evidente en "El evangelio según Marcos" y de forma alusiva en textos como "Tema del traidor y del héroe", "El muerto" o "La intrusa", la literatura borgeana reescribe la historia del sacrificio de Cristo, recuperando algunos episodios o rasgos de su figura en diversos textos. ${ }^{6}$ Jesús, por lo tanto, tiene una centralidad indudable en la

\footnotetext{
El Index puede consultarse en línea en el sitio web del Borges Center de la Universidad de Pittsburgh: http://www.borges.pitt.edu/index/jesucristo

5 Ver por ejemplo "El otro" — relato publicado en 1972 y recogido en El libro de arena-: "Padre siempre con sus bromas contra la fe. Anoche dijo que Jesús era como los gauchos, que no quieren comprometerse, y que por eso predicaba en parábolas" (OCIII: 13).

6 Para un desarrollo de este punto, remitimos a Adur (2016b), donde proponemos la serie de "cuentos de sacrificio" que, en la obra de Borges, pueden leerse como reescrituras de la historia de Cristo.
} 
obra borgeana: como figura histórica — quizás la más importante de Occidente-, como motivo artístico y literario, y como modelo para la propia escritura.

La segunda cuestión en la que queremos detenernos brevemente antes de comenzar nuestro análisis se vincula con un punto que ha sido objeto de algunos debates de la crítica ¿Cómo se sitúa Borges frente a Jesús o, más generalmente, frente al cristianismo como religión? ¿Ateo, creyente, buscador, agnóstico? Se han ensayado diversas respuestas a estas preguntas ( $c f$., por ejemplo, Soldani 1994, Zagal Arreguin 1999, Muñoz Rengel 2000, D’Angelo 2005, Flynn 2009, Navarro 2009). Proponemos - recuperando lo desarrollado en nuestra tesis doctoral- que, para plantear adecuadamente la cuestión, debe despejarse todo intento de "descubrir" las creencias personales del autor - como sucede en varios de los estudios que citamos-, para procurar describir su posicionamiento de escritor. Este surge de un complejo proceso dialéctico que involucra, entre otros elementos, la obra de Borges, su imagen pública, los medios de difusión que elige — revistas, editoriales-, los grupos o cenáculos en los que participa, sus declaraciones en entrevistas y las relaciones que entabla con otros escritores o actores del campo literario. Es este posicionamiento —que, evidentemente, está vinculado a sus creencias personales, pero no se equipara con estas- lo que resulta relevante para determinar los efectos de sentido de la literatura borgeana y, particularmente en lo que nos ocupa, su perspectiva sobre la figura de Jesús.

No podemos detenernos aquí en definir detalladamente el posicionamiento borgeano frente al cristianismo, por lo que nos limitaremos a caracterizarlo en tres puntos. ${ }^{7}$ En primer lugar, se trata de un posicionamiento dinámico. Como con respecto a muchos tópicos, la forma de abordar la figura de Jesús no es monolítica en la larga trayectoria del escritor, sino objeto de desplazamientos y transformaciones. Así, para decirlo muy sucintamente, el Borges de fines de los años veinte, que escribía en medios católicos como

\footnotetext{
7 Para una exposición más completa de este tema, $c f$. Adur (2014).
} 
la revista Criterio, participaba en el cenáculo Convivio y declaraba "en trance de Dios y de inmortalidad soy de los que creen" (Borges [1928] 1998:72), tiene una posición con respecto a Jesús —y al cristianismo- que no es exactamente la misma que comenzará a cristalizar en los años treinta, cuando rompe definitivamente con los católicos argentinos y proclama insistentemente su incredulidad en cuestiones religiosas. Este posicionamiento que podemos denominar agnóstico - en un sentido singular, como veremos enseguida- es el más estable entre las décadas del treinta y el cincuenta - período en el que Borges publica sus libros más importantes-. Sin embargo, debe matizarse hacia la segunda mitad del siglo, cuando encontramos textos — como el ya citado "Paradiso..." o "Lucas XXIII" - publicado en Sur en 1961 e incluido posteriormente en El hacedor- donde la figura de Cristo es objeto de una valoración que se desplaza desde lo estético a lo ético e incluso, en algunos textos, a lo espiritual o religioso. Aunque en este trabajo en particular proponemos un acercamiento panorámico a la obra de Borges - lo que implica poner en diálogo textos de distintas épocas- consideraremos -y señalaremos, cuando sea pertinente- los desplazamientos existentes entre las diferentes etapas de la producción del escritor.

La crítica — retomando declaraciones del propio Borges- ha insistido en definir la relación del escritor con el cristianismo - $-\mathrm{y}$ con prácticamente cualquier credo o sistema de ideas-en términos de agnosticismo. ${ }^{8}$ En efecto, como dijimos, se trata de su posicionamiento más estable, el que involucra la redacción de sus obras más importantes y el que, con algunos matices, puede extenderse a su producción de los últimos años. Es preciso, sin embargo, puntualizar en qué sentido debe entenderse este posicionamiento agnóstico. El agnosticismo sostiene la incognoscibilidad radical de

\footnotetext{
8 Para mencionar solo algunos casos relevantes, Kodama (1996), Lefere (1998), Pauls (2000), Sarlo (2003) y Magnavacca (2009) definen al escritor como “agnóstico”. Se trata, sin embargo, de un término que no está presente en la obra borgeana de los años 30-50. Lo encontramos recién en entrevistas de la década del sesenta y posteriores (por ejemplo, Milleret 1970: 114; Vázquez 1977: 107).
} 
lo trascendente -fundamentalmente, para lo que nos ocupa, de la existencia de una divinidad-. Pero en el caso de Borges, tiene un matiz singular: la incognoscibilidad de lo divino no implica el silencio acerca de este tópico y otros anejos. Lejos de suscribir la sentencia de Wittgenstein acerca de que "de lo que no se puede hablar hay que callar" (2003: 132), las indagaciones e hipótesis sobre lo divino proliferan en la obra borgeana, exhibiendo en muchos casos no solo creatividad sino cierto conocimiento de autores y conceptos centrales. Un agnosticismo que no se llama al silencio, un agnosticismo interesado, podríamos decir, para recuperar una noción a la que Borges acude para definir la atracción que suscita un discurso al que no se le concede, necesariamente, valor de verdad. ${ }^{9}$

Por último, podemos caracterizar el posicionamiento de Borges con respecto a la figura de Jesús como profanatorio, retomando el concepto de profanación que propone Giorgio Agamben. El filósofo italiano sostiene que la muy difundida etimología que deriva religión (religio) de religare ("lo que liga y une lo humano y lo divino") es errónea. La religión "no es lo que une a los hombres y a los dioses, sino lo que vela por mantenerlos separados, distintos unos de otros" (2009: 99). De este modo, define dos operaciones de signo contrario. Por un lado, la consagración, que sustrae las cosas, lugares o personas del uso común y las transfiere a una esfera separada — sagrada-; por otro, la profanación que las restituye "al libre uso de los hombres” (Agamben 2009: 97-99). La relación que la obra de Borges establece con la figura de Cristo o, más ampliamente, con la Biblia y la teología cristianas, puede pensarse en términos de un uso que las despoja de cualquier aura de sacralidad. Especialmente a partir de sus ensayos y ficciones publicados entre 1930 y comienzos de la década del cincuenta, Borges contribuye a inaugurar en el campo

\footnotetext{
$9 C f$., en este sentido, "Leslie D. Weatherhead: After Deatb" — "me interesa y no creo" (OCI: 281)—; "La muerte y la brújula” — “Usted replicará que la realidad no tiene la menor obligación de ser interesante. Yo le replicaré que la realidad puede prescindir de esa obligación, pero no las hipótesis”, (OCI: 500)—; “ “Deutsches Requiem” — “Antes, la teología me interesó, pero de esa fantástica disciplina (y de la fe cristiana) me desvió para siempre Schopenhauer [...](OCI:577)—.
} 
literario argentino un modo de relación con el cristianismo que, sin subordinar el discurso literario al teológico —como lo hacían algunos de sus contemporáneos católicos-, no se reduce tampoco a una burla o denuncia del carácter mítico (en el sentido de falso o falsario) de los relatos y los desarrollos especulativos que sustentan la religión. En este sentido, podemos hablar de una (re)apropiación para la literatura "profana" de temas que parecían limitados a los intelectuales confesionales. Como recordará en "El enigma de Edward Fitzgerald”, "todo hombre culto es un teólogo, y para serlo no es indispensable la fe" (OCII: 66). Borges restituye los temas teológicos y bíblicos al libre uso de los escritores. ${ }^{10}$

Planteadas entonces la relevancia de Jesús y la forma en que proponemos considerar el posicionamiento de Borges, nos abocaremos, a continuación, al examen de las múltiples referencias a la figura de Cristo que despliega la obra del escritor. Como anticipamos, organizaremos el análisis en tres imágenes principales: la del Crucificado, la del Poeta o Maestro oral y la del Verbo encarnado. ${ }^{11}$

\section{El crucificado}

La figura de Cristo como crucificado es indudablemente la más recurrente en la obra de Borges. Como ha señalado Navarro (2009: 483), la mayoría de las menciones de Jesús, aun las más breves, incluyen alguna referencia a su crucifixión y muerte. ${ }^{12}$ La preponderancia

\footnotetext{
10 Obras como Falsificaciones de Mario Denevi (1966), El otro Judas (1961) o El evangelio según van Hutten (1999) de Abelardo Castillo e incluso Vidas de santos (1993) de Rodrigo Fresán están — declaradamente- en continuidad con esta línea profanatoria inaugurada por la literatura borgeana.

11 Es necesario consignar aquí nuestra deuda con el trabajo de Gonzálo Salvador Vélez (2008) de quien retomamos esta propuesta de tripartición de las imágenes sobre Jesús, aunque el desarrollo que proponemos para las mismas y las articulaciones entre ellas se apartan de la lectura del crítico español.

12 Para mencionar algunos ejemplos de distintas épocas y géneros: “muriendo en lo alto como Jesús" (OCI: 89); “Lo que hace un hombre es como si lo hicieran todos los hombres. Por eso no es injusto que una desobediencia en un jardín contamine al género humano; por eso no es injusto que la crucifixión de un solo judío baste para salvarlo" (OCI: 493); “...Cristo que se muere en el madero” (OCII:259); “pero después la sangre
} 
de esta imagen puede entenderse como una opción del escritor por privilegiar el momento que expresa de modo más dramático la humanidad, la condición mortal de Jesús. En contraste, las alusiones a milagros o a la resurrección, donde se plantearía la cuestión de la potencial divinidad de Cristo, están prácticamente ausentes en la obra de Borges ( $c f$. Fresko 2002: 29, Vélez 2008: 208). Como ha señalado Susanna Fresko, para el escritor, "Gesù Cristo è, prima di ogni altra cosa, un uomo, 'un giudeo', che soffre [...]. Gesù Cristo è un'agonia” (2002: 19).

La agonía de Jesús en la cruz tendrá, además, en la obra de Borges -al menos en algunos textos- un valor modélico: en la forma de enfrentar la muerte, de aceptar su destino, Jesús funciona como modelo para una serie de personajes borgeanos - desde los cuchilleros o compadritos de los primeros textos a los guerreros sajones o nórdicos de la última etapa- que no desesperan, ni siquiera ante la inminencia de la muerte. ${ }^{13}$ Piénsese, por ejemplo, en Francisco Real, la víctima de "Hombre de la esquina rosada", uno de los primeros relatos de Borges: luego de haber sido arreado "[...] como un cristo, casi de punta a punta, a pechadas, a silbidos, y a salivazos" y, más tarde, asesinado por el narrador, muere en silencio, "sin queja", y pidiendo que le tapen la cara para que no "le curiosearan los visajes de la agonía” (OCI: 332). Daniel Nahson propone, en este sentido, que podrían trazarse relaciones entre la actitud ante la muerte de "Cristo en la cruz" y la de los personajes de "Poema conjetural", "El Sur", "Deustches Réquiem" e "Isidoro Acevedo": "La intrepidez del culto del coraje y el arrojo a la heroicidad de la muerte

del martirio/ el escarnio, los clavos y el madero" (OCII: 271); "Sé que estás en el sagrado / Libro que abarca el tiempo y que la historia / del rojo Adán rescata la memoria / y la agonía del crucificado" (OCII:374; "...pendí de una cruz" (OCII: 355); "fue los oscuros clavos que atravesaron la carne del Redentor y el leño de la Cruz (OCII: 231); "en un atardecer muere un judío crucificado por los negros clavos (OCIII: 114).

13 Esta actitud modélica ante la muerte permitiría asociar a Jesús con otra gran figura fundacional de Occidente: la de Sócrates. Diversos textos borgeanos parecen sugerir un paralelo entre el nazareno y el filósofo ateniense, quien acepta sin estridencias su condena a muerte y bebe la cicuta. Véase textos como "Otro poema de los dones" (OCII: 314), "In memoriam JFK" (OCII: 231) o "No eres los otros" (OCIII: 158), donde las muertes de Jesús y de Sócrates son mencionadas contiguamente, posibilitando la asociación que indicamos. 
soñada de Borges”, afirma el crítico, “se confunden con la entereza de la entrega de Cristo en la cruz” (2009:190). Agreguemos que una exacerbación de esta imagen de Jesús aceptando valientemente su muerte puede encontrarse en algunas alusiones dispersas, a partir de los años cincuenta, en las que Borges, retomando tradiciones de poesías anglosajonas y de las sagas escandinavas, habla del "Cristo blanco" - ver por ejemplo "La apostasía de Coifi” (TR2: 308), "El dios y el rey" (TR2: 328-329) o "Einar Tambarskelver" (OCIII: 146) - . Alude así a la imagen de Jesús como un “joven héroe”, cuya decisión no flaquea en el momento de subir a la cruz para enfrentar su muerte, tal como se imagina en "El sueño de la cruz", poema anglosajón anónimo, aludido y citado repetidas veces por el escritor. ${ }^{14}$ En esta composición anónima, la Cruz habla y declara:

Luego vi al Rey de toda la humanidad con valeroso ánimo apresurarse a subírseme encima. [...] Luego el joven Guerrero, Dios, el Todopoderoso, se quitó las vestiduras, resuelto y fuerte; con señorial coraje a la vista de muchos se subió a la Cruz para redimir a la humanidad. Cuando el Héroe me agarró temblé de terror [...] (citado en Borges y Kodama 1978: 14).

Además de este valor modélico que tiene la muerte de Jesús en la cruz, debe destacarse también su componente dramático. Como ha señalado Navarro (2009), generalmente, al hablar de la pasión de Cristo, Borges introduce categorías dramáticas: "funciones” (OCI: 388), "teatro" (OCII: 80), “actores”, “tragedia” (OCIII: 39). Proponemos que este carácter dramático puede entenderse en dos sentidos. En primer lugar, responde al dramatismo - al patetismo, en el sentido de pathos- que el escritor percibe en los relatos evangélicos. Esto queda claramente explicitado en el contraste entre la historia de Jesús y la de Buda, que Borges propone en la introducción al budismo que escribió junto a Alicia Jurado:

14 Cf. "Visión o sueño de la cruz" (Borges y Vázquez [1965] 1998: 33-34), "Una oración” (OCII: 392). Borges también se refirió a este texto en sus clases de literatura inglesa en la Universidad de Buenos Aires en 1966 (2000a: 101-ss) y en entrevistas (Ferrari 1999:101). Además, lo incluirá en su Breve antología anglosajona. 
Para el occidental, la comparación de la historia o leyenda del Buddha con la historia o leyenda de Jesús es quizás inevitable. Esta última abunda en inolvidables rasgos patéticos y en circunstancias de insuperable dramaticidad; comparada con la de un dios que condesciende a tomar la forma de un hombre y muere crucificado con dos ladrones, la otra historia del príncipe que deja su palacio y profesa una vida austera es harto más pobre (Borges y Jurado [1976] 1991: 30-31) [el destacado es nuestro].

En distintos lugares, Borges insiste en que, más allá de la - supuesta- significación religiosa de la Pasión, la perfección dramática de la escena la vuelve inolvidable. En las palabras pronunciadas, en la actitud del protagonista ante la muerte, en la forma en que esta se produce y en el papel que desempeñaron todos los "actores" - los voluntarios y los involuntarios, como dice en “La Secta de los Treinta” (OCIII: 39)—, se encuentra la clave por la que es posible afirmar que "la historia no dejará que muera la memoria de aquella tarde” (OCII: 218), y que los hombres seguirán repitiéndola por siempre (OCII: 446).

En segundo lugar, el dramatismo de la pasión tiene también, para Borges, el sentido de representación, de puesta en escena deliberadamente memorable. En efecto, el crucificado es considerado como un actor — "La Secta de los Treinta" — que se atiene voluntariamente a un papel, que sigue un guión, pautado por Dios desde el origen de los tiempos. Leemos, en este sentido, en "El Biathanatos": "[...P] ara teatro de esa muerte futura, creó la tierra y los cielos. Cristo murió de muerte voluntaria [...], y ello quiere decir que los elementos y el orbe y las generaciones de los hombres y Egipto y Roma y Babilonia y Judá fueron sacados de la nada para destruirlo" (OCII: 80).

Esta posibilidad de pensar la crucifixión como un drama escrito por otro (por Otro), que Jesús se limita a representar hasta la muerte -lo que tiene implicancias teológicas que ya han sido señaladas por Navarro (2009) - parece ser explorada, aunque de un modo algo oblicuo, en uno de los más notables relatos de Borges, “Tema del traidor y del héroe” — publicado en Sur, en 1944 y recogido 
ese mismo año en Ficciones-. ${ }^{15}$ Kilpatrick, el protagonista, se nos presenta con una serie de rasgos que parecen remitir a la figura de Cristo: joven, heroico, bello, de "piadosos hábitos", asesinado y con un sepulcro que fue "misteriosamente violado" (OCI: 497-498). Este patriota irlandés resultará ser un traidor y un grupo de conjurados decidirá sacrificar su vida "para la emancipación de la patria” - lo que recuerda la conjura del Sanedrín y la decisión de Caifás en el Evangelio de Juan (11, 50, Reina Valera [1909] 2011): “conviene que un hombre muera por el pueblo y no que toda la nación se pierda"- . ${ }^{16}$ Ahora bien, este personaje cristológico será actor voluntario en una muerte que es pura representación, un montaje que busca lograr escenas suficientemente patéticas como para perdurar en la "memoria apasionada de Irlanda" (OCI: 498). Los pasajes que narran la planificación y la implementación del proceso que desemboca en el asesinato de Kilpatrick están repletos de referencias teatrales. Sabemos que Nolan, su autor intelectual, se ha inspirado en Shakespeare y en las Felstpiele de Suiza; se dice que la muerte y los días que la precedieron fueron parte de un "drama", en el que la entera ciudad funcionó como escenario y los actores fueron legión - lo que anticipa las convicciones de la Secta de los Treinta-. Como el disparo que acaba con la vida de Kilpatrick en "un palco de funerarias cortinas", la cruz es el acto final de un "populoso drama” (OCI: 498), cuidadosamente planificado: "Quizá el hierro fue creado para los clavos y las espinas para la corona de escarnio y la sangre y el agua para la herida”, conjetura Borges en el ya citado ensayo sobre el Biathanatos (OCII: 80).

Queremos detenernos en un último rasgo de esta imagen de Jesús como crucificado que resulta relevante para la poética borgeana. Hemos afirmado, al inicio de este apartado, que prácticamente todas

\footnotetext{
15 Hemos desarrollado una lectura del cuento en este sentido en Adur (2016b), al que remitimos. Exponemos aquí solamente los puntos más relevantes para nuestra argumentación.

16 Todas las referencias a la Biblia a lo largo de este trabajo remiten a la edición conocida como Reina Valera [1909] 2011. Hemos fundamentado la prioridad de esta versión de la Escritura como fuente de las citas bíblicas de Borges, en Adur (2016a).
} 
las referencias a Jesús en la obra de Borges incluyen alguna mención de su pasión y muerte. No es una mera constatación cuantitativa: la crucifixión es ineludible y funciona como una suerte de sinécdoque de toda la vida de Cristo. Es allí donde se condensa y se revela su identidad. ${ }^{17}$ En "Biografía de Tadeo Isidoro Cruz"—el apellido no deja de ser significativo-, Borges dejó dicho que "Cualquier destino, por largo y complicado que sea, consta en realidad de un solo momento: el momento en que el hombre sabe para siempre quién es” (OCI: 562). Aunque el propio escritor haya referido a Dante este recurso de definir la vida entera de un hombre a partir de una escena o rasgo esencial, ${ }^{18}$ es posible pensar que la crucifixión de Jesús funciona como un modelo o, al menos, un ejemplo cabal de este recurso. Recordemos que, en muchos textos borgeanos, esta epifanía de la propia identidad acontece - como en la cruz- en estrecha vinculación con la muerte - pensemos en "La otra muerte", "Poema conjetural”, “El Sur”, "Elogio de la sombra”, "Undr” o "Correr o ser", para mencionar algunos ejemplos-.

La imagen de Jesús como crucificado conlleva entonces, en primer lugar, una perspectiva que se concentra más en su humanidad - y corporalidad - que en su divinidad. En segundo lugar, se tiene un modelo de cómo enfrentar la muerte, que es celebrado en ciertos poemas "nórdicos" y emulado por los compadritos que adscriben a la "ética del coraje" en algunas ficciones borgeanas. En tercer lugar, la Cruz funciona como una imagen dramática, de un patetismo que la vuelve inolvidable, y que se puede pensar como deliberado. Por último, la crucifixión es, en muchos lugares de la obra de Borges, sinécdoque de toda la vida de Cristo, lo que resulta quizás modélico para el recurso borgeano de cifrar una vida en un instante.

\footnotetext{
17 Según numerosos exégetas, a una conclusión análoga puede arribarse a partir de una lectura del evangelio de Marcos: es en la muerte donde se revela el carácter mesiánico de Jesús.

18 "Yo he querido hacer lo mismo en muchos cuentos y he sido admirado por ese hallazgo, que es el hallazgo de Dante en la Edad Media, el de presentar un momento como cifra de una vida", afirma en una conferencia sobre "La divina comedia", (OCIII: 213).
} 
3. Jesús como orador: el poeta y el maestro

Hemos dicho que la imagen de Jesús en la cruz aparece tempranamente en Borges, ya en los poemas de los años veinte. A partir de los años cincuenta - con algunos antecedentes aislados- comenzamos a encontrar, con cierta frecuencia, consideraciones no solo sobre la pasión y la muerte de Jesús, sino también sobre su discurso, sus palabras y frases, tal como han sido recogidas en los evangelios.

En el ya citado "Cristo en la cruz", el legado de Jesús se valora en los siguientes términos: "nos ha dejado espléndidas metáforas / y una doctrina del perdón capaz de anular el pasado" (OCIII: 453). El poeta distingue aquí dos dimensiones en su apreciación de la palabra de Jesús: una estética — las espléndidas metáforas- y una ética la doctrina del perdón-.${ }^{19}$ De este modo, quedan delineadas dos facetas posibles de la imagen de Cristo: la del poeta y la del maestro. Aunque se trata de imágenes estrechamente interrelacionadas, a los fines de nuestro análisis las consideraremos separadamente.

\subsection{Jesús como poeta}

La valoración de Jesús como poeta u "hombre de letras" —como Borges lo menciona en su reseña de "Libro para la pausa del sábado" (TR2:15) — puede confundirse con la famosa consideración estética de la metafísica y la teología, que el autor proclama en el epílogo de Otras inquisiciones (OCII: 153). Sin embargo, debemos distinguirla cuidadosamente de esta. Al abordar, por ejemplo, las hipótesis de teólogos como P.H. Goose (OCII: 28-ss) o Leslie D. Weatherhead (OCI: 280-281), Borges realiza una operación de lectura que le permite valorar estéticamente - leer como literatura, incluso como "literatura fantástica" - aquello que originalmente se presentaba como un discurso especulativo. En el caso de Jesús, en cambio, Borges subraya — como, por otra parte, ha sido señalado por varios escritores-que estamos ante un discurso deliberadamente poético,

\footnotetext{
$19 C f$., en el mismo sentido, “Alguien sueña” donde se alude a "la ética y las metáforas del más extraño de los hombres, el que murió una tarde en una cruz" (OCIII: 467). Reencontramos allí ética y estética.
} 
que no recurre a elucubraciones abstractas sino a imágenes y ejemplos concretos: "No usó nunca argumentos: la forma natural de su pensamiento era la metáfora", afirma en su prólogo a los Evangelios apócrifos (OCIV: 480). El escritor desarrolla especialmente este punto en sus clases de Literatura inglesa en la Universidad de Buenos Aires, en 1966:

Cristo se expresa a sí mismo por parábolas, es decir por poemas. Cristo dice, por ejemplo: "Yo no he venido a traer la paz sino...", y el entendimiento abstracto esperaría: “[...] sino la guerra”. Pero Cristo, que es un poeta, dice: "Yo no he venido a traer la paz, sino una espada"; "El que esté sin culpa que arroje la primera piedra", etc. [...]. Es decir, usa siempre ejemplos concretos, es decir, ejemplos poéticos (Borges 2000b: 213). ${ }^{20}$

La predicación de Jesús, en este sentido, participa de la oposición entre el discurso teológico - y especialmente el escolástico-, abstracto y conceptual, y la palabra bíblica - de la que los evangelios son una de las cumbres-, concreta y poética. Así, como afirma en "El primer Wells": "La realidad procede por hechos, no por razonamientos; a Dios le toleramos que afirme (Éxodo, 3, 14) « Soy El Que Soy», no que declare y analice, como Hegel o Anselmo, el argumentum ontologicum. Dios no debe teologizar" (OCII: 76). La opción por una expresión poética parece más adecuada para un (hijo de) Dios que los desarrollos interminables e insignificantes de la escolástica. ${ }^{21}$ Aún más: Borges, en distintos momentos, declara su preferencia por un Dios "concreto" como el de los primeros capítulos del Génesis OCII: 115), "un dios humano, un dios chambón" (Borges 1999: 194), con actitudes y pasiones humanas —lo que

20 Esta valoración del estilo de Jesús la encontramos también en varias de las entrevistas que Borges concede a partir de los años sesenta. Así, por ejemplo, en una conversación con Ferrari: "nadie ha encontrado imágenes tan extraordinarias como las de Cristo; imágenes que al cabo de dos mil años siguen siendo asombrosas” (Ferrari 1999:97).

21 La escolástica, considerada como epítome de la teología racionalista, es objeto del desdén borgeano en varios textos. Cf. por ejemplo "La duración del infierno" — “frivolidad escolástica” (OCI: 237)—; "Historia de la eternidad” — "la sospecha de que las categorías de Dios pueden no ser precisamente las del latín, no cabe en la escolástica” (OCI: 360)—. 
evidentemente se acerca a la concepción de Jesús como Dios encarnado, ver infra-, por sobre el "respetuoso caos de superlativos no imaginables" delineado por los teólogos —como afirma en "De alguien a nadie" (OCII: 115). En este sentido, la valoración de la expresión poética y singular de Jesús - y de su propia naturaleza como persona concreta, "la figura más vívida de la memoria humana” (OCIV: 480) — por sobre las abstracciones filosóficas y teológicas, es parte de un posicionamiento estético que constituye uno de los pilares de la poética borgeana: "El arte, siempre, opta por lo individual, lo concreto; el arte no es platónico” (OCI: 180). Esta convicción puede rastrearse, en distintas manifestaciones, a lo largo de toda la producción del autor: en la preferencia por las novelas - que se ocupan de lo literal y lo concreto- frente a las alegorías, "seudo-humanización de voces abstractas" ("La conducta novelística de Cervantes" [1928] 1998:55);22 en su valoración de Martín Fierro como el ejemplar “más individual” de la tradición gauchesca (OCI:180); en su elección de ejemplos concretos en lugar de definiciones conceptuales; ${ }^{23}$ y quizás, incluso, en el afán enumerativo, de nombrar, de mencionar las cosas concretas, las "comunes cosas” (OCIII: 488) que se encuentra en buena parte de su poesía, especialmente en la de madurez — $c f$. por ejemplo "Mateo 25, 30" (OCII: 252), “Las cosas” (OCII: 370), "Buenos Aires” (OCII: 387-388)—. ${ }^{24}$ La consideración de Jesús en tanto poeta implicaría, entonces, situarlo en un posicionamiento estético afín al que el propio Borges defiende y practica.

Para finalizar, queremos referirnos brevemente a dos autores que parecen haber sido decisivos en la interpretación de Jesús como

\footnotetext{
22 Sobre la contraposición entre alegoría y novela, $c f$. también la reseña sobre $E l$ Buque (TR2:135), "Sobre una alegoría china" (TR2: 200) y “De las alegorías a las novelas" (OCII:122).

${ }^{23}$ Cf. por ejemplo "El espejo de los enigmas”: “¿Qué es una inteligencia infinita?, indagará tal vez el lector. No hay teólogo que no la defina; yo prefiero un ejemplo. Los pasos que da un hombre, desde el día de su nacimiento hasta el de su muerte, dibujan en el tiempo una inconcebible figura. La Inteligencia Divina intuye esa figura inmediatamente, como la de los hombres un triángulo" (OCII:100).

24 Sobre la poética de lo concreto en Borges, $c f$. Sucre (1968).
} 
poeta que propone Borges. El primero es William Blake, a quien el escritor parece remitir el descubrimiento de una preocupación estética en Jesús. Este se presenta como parte de lo que podemos denominar una "teoría de la salvación en tres etapas"-Jesús, Swedenborg, Blake-, que Borges desarrolla sobre todo en una serie de clases y conferencias ( $c f$. Almeida 2000: 146 y Nahson 2009: 244):

Siempre se ha pensado que la salvación es de carácter ético. Se entiende que si un hombre es justo, se salva. El reino de los cielos es de los pobres de espíritu, etcétera. Eso lo comunica Jesús. Pero Swedenborg va más allá. Dice que eso no basta, que un hombre tiene que salvarse también intelectualmente. [...] Y luego vendrá William Blake, que agrega una tercera salvación. Dice que podemos -que tenemos- que salvarnos también por medio del arte. Blake explica que Cristo también fue un artista, ya que no predicaba por medio de palabras sino de parábolas. Y las parábolas son, desde luego, expresiones estéticas. Es decir, que la salvación sería por la inteligencia, por la ética y por el ejercicio del arte (OCIV:199). ${ }^{25}$

Además de Blake, puede mencionarse otra posible fuente de esta valoración estética del discurso de Jesús en una obra que marcó un hito en los modos de comprender su figura - y de recrearla literariamente, $c f$. Ziolkowski (1982)—: la Vida de Jesús (1863) de Ernest Renan. Retomando las investigaciones de Strauss, Renan propone un abordaje histórico de Jesús, que rechaza todo componente sobrenatural. ${ }^{26}$ Borges cita este libro al menos en dos ocasiones -hacia fines de los años veinte, en una nota titulada "El lado de la muerte en Güiraldes” (TR2: 346) y en uno de sus últimos diálogos con Ferrari, en 1985 (Borges y Ferrari 1999: 97)—, pero lo que nos interesa aquí es que la perspectiva del historiador francés es concurrente con la lectura del escritor argentino.

En principio, podemos subrayar que en ambos encontramos la afirmación de la existencia histórica de Jesús. Renan la toma como

25 Cf. también Borges y Vázquez (1997: 95), Borges (2000b: 211).

26 Generalmente, la Vida de Jesús de Renan no ha sido considerada en relación con la producción borgeana. Nos hemos detenido en esta cuestión en Adur (2010a), trabajo del que retomamos aquí algunos de los puntos principales. 
un punto de partida indudable. Pese a sus numerosas objeciones a los relatos evangélicos —a los que califica de "biografías legendarias" ([1863] 2003: 64)—, niega de plano la posibilidad de que Jesús sea un invento de los evangelistas: "Lejos de que Jesús haya sido creado por sus discípulos, Jesús se muestra en todo superior a sus discípulos, que [...] eran hombres sin invención ni genio" (Renan [1863] 2003: 297). ${ }^{27}$ Del mismo modo, su historicidad nunca es puesta en cuestión por Borges, y es afirmada en distintos momentos — $f$. "El testigo" (OCII: 174), "El pudor de la historia” (OCII: 132), el ya citado prólogo a Evangelios apócrifos (OCIV: 480)—. En este sentido, Vélez señala el contraste entre el tratamiento que Borges hace de la figura de Adán, considerada como símbolo literario, y la de Jesús a quien "no puede dejar de considerar como un personaje histórico" (2008: 198). Se acepta su existencia pero se rechaza su divinidad; tal parece ser el primer movimiento en Renan y en Borges. Sin embargo, en ambos autores, la divinidad o las capacidades sobrenaturales, negadas al sujeto, parecen desplazarse - en una suerte de efecto compensatorio- a su discurso. Así, considerando las admoniciones dirigidas contra los fariseos, Renan concluye: “Estas obras maestras de la más elevada ironía, han grabado sus rasgos con líneas de fuego sobre la carne del hipócrita y del falso devoto ¡Rasgos incomparables, rasgos dignos de un hijo de Dios!” ([1863] 2003: 239). Borges, por su parte, llega a afirmar que "imaginar una sola frase que sin desdoro pueda soportar la proximidad de las que han conservado los Evangelios, excede, acaso, la capacidad de la literatura" (Borges y Edelberg [1955] 1998: 75). En esta misma cita, podemos ver que el discurso “divino" de Jesús es considerado por Renan desde una perspectiva estética (“obras maestras”). El historiador se referirá en su obra al “alma lírica” del nazareno y a sus "aforismos concisos, de una forma expresiva, a veces enigmática y extravagante” (Renan [1863] 2003:

\footnotetext{
27 Significativamente, esta afirmación recuerda a una que Borges realiza a Ferrari en la misma entrevista en que cita a Renan. Cuando el entrevistador insinúa la no historicidad de Cristo, Borges responde: "Yo creo que no hay ninguna duda, porque si no tendríamos que suponer, digamos, cuatro dramaturgos, muy superiores a todos los demás poetas del mundo, creando esa figura" (Ferrari 1999: 103).
} 
113-296) para señalar, tal como hemos visto en el caso de Borges, su tajante contraposición con la abstracción de las proposiciones teológicas: "Sería vano buscar en el Evangelio una proposición teológica. Todas las profesiones de fe son disfraces de la idea de Jesús” (Renan [1863] 2003: 296).

\subsection{Maestro oral}

Como anticipamos, no es exclusivamente esta valoración estética del discurso de Jesús en tanto poeta la que se encuentra en la obra de Borges, sino también -y quizás de un modo más recurrentela de su doctrina ética, que permite definirlo como un maestro, y un maestro oral. La primera mención significativa en este sentido la encontramos en 1951, en el ensayo "Del culto de los libros". Borges acumula argumentos contra la palabra escrita de pensadores antiguos, hasta llegar a la siguiente declaración de Clemente de Alejandría: "Escribir en un libro todas las cosas es dejar una espada en manos de un niño”. A continuación, asegura que esas palabras derivan de las evangélicas: "No deis lo santo a los perros ni echéis vuestras perlas delante de los puercos, porque no las huellen con los pies, y vuelvan y os despedacen'. Esta sentencia es de Jesús, el mayor de los maestros orales, que una sola vez escribió unas palabras en la tierra y no las leyó ningún hombre (Juan, 8:6)" (OCII: 92).$^{28}$

El énfasis aquí, acorde con el tema del ensayo, está ante todo en el carácter oral de las enseñanzas de Jesús, que lo conecta con el mundo antiguo. Sin embargo, juzgarlo como "el mayor de los maestros orales" apunta al carácter superlativo de sus enseñanzas que, como Borges explicita años después, en el prólogo

\footnotetext{
28 Esta escena parece haber impresionado singularmente a Borges, que ya la había recuperado para atribuirla a uno de los personajes de "El inmortal": "Estaba tirado en la arena, donde trazaba torpemente y borraba una hilera de signos, que eran como las letras de los sueños, que uno está a punto de entender y luego se juntan [...]. El hombre las trazaba, las miraba y las corregía. De golpe, como si le fastidiara ese juego, las borró con la palma y el antebrazo" (OCI: 538). Reencontramos una evocación de esta escena en el ya citado prólogo a los Evangelios apócrifos: "Salvo aquellas palabras que su mano trazó en la tierra y que borró en seguida, no escribió nada” (OCIV: 480).
} 
a la Obra crítica de Henríquez Ureña, lo sitúa como un maestro -literalmente- excepcional:

Maestro es quien enseña con el ejemplo una manera de tratar con las cosas, un estilo genérico de enfrentarse con el incesante y vario universo [...]. Quien haya recorrido con fervor los diálogos socráticos, las “Analectas” de Confucio o los libros canónicos que registran las palabras y sentencias del Buddha, se habrá sentido defraudado más de una vez; la oscuridad o la trivialidad de tal o cual dictamen, piadosamente recogido por los discípulos, le habrá parecido incompatible con la fama de esas palabras, que resonaron, y siguen resonando, en lo cóncavo del espacio y del tiempo. (Que yo recuerde, los evangelios nos ofrecen la única excepción a esta regla, de la que ciertamente no se salvan las conversaciones de Goethe o de Coleridge) (OCIV: 87).

La enseñanza ética de Jesús aparece como una de las más altas que ha alcanzado la humanidad. ${ }^{29}$ Tal apreciación, aunque excede lo estrictamente estético, no está reñida con la imagen del escritor como agnóstico, que ya estaba consolidada en los años cincuenta. En tanto no conlleva ningún tipo de creencia - el magisterio de Jesús se percibe “más allá de nuestra falta de fe” (OCIV: 480) —, la valoración ética del maestro oral puede integrarse sin demasiados problemas con la valoración estética del poeta. Esta conjunción se encuentra con frecuencia en las entrevistas concedidas por Borges en la segunda mitad del siglo XX ( $c f$. por ejemplo Vázquez 1977: 101-ss, Ferrari 1999:97-ss).

La imagen de Jesús como maestro oral confluye con la del crucificado, que antes comentamos, en uno de los personajes más explícitamente cristológicos de los relatos de Borges: Baltasar Espinosa, protagonista de "El evangelio según Marcos”. Este estudiante

\footnotetext{
29 También en el “Testimonio de Borges” sobre Macedonio Fernández (1974), Jesús es considerado - como Sócrates, Pitágoras o Buda - uno de los "genios que no escribieron nunca” (TR3: 173). En el prólogo a Evangelios apócrifos (1985), se insiste en que fue, como Buda, un maestro oral, que "ha gobernado, y sigue gobernando, el curso de la historia” (OCIV: 480). "Maestro" es también el título con el que se alude a Jesús en "Otro fragmento apócrifo” (OCIII: 485).
} 
de medicina, que se destacaba por su "facultad oratoria", comienza por "predicar las parábolas" — restableciendo la oralidad subyacente al texto escrito- $y$, finalmente, muere en una improvisada cruz, "para salvar a todos del infierno" (OCII: 447).

Pero el texto que resulta clave para pensar el trabajo reescriturario de Borges sobre los discursos poético-magisteriales de Jesús es "Fragmentos de un evangelio apócrifo" (OCII: 389-390). "Fragmentos..." reescribe, en una serie de versículos numerados discontinuamente, distintos textos evangélicos —en su mayoría del llamado Sermón del Monte, capítulos 5 a 7 del evangelio según Mateo- de un modo cercano a lo que Genette define como "parodia mínima": "retomar un texto conocido para darle una significación nueva, jugando, si hace falta y tanto como sea posible con las palabras" (1989:27).

En alguno de los fragmentos se insinúa una lectura en clave estética de las palabras de Jesús: "No jures, porque todo juramento es un énfasis", sentencia que no solo remite a Mateo 5, 37, sino que está en línea con la condena del énfasis que Borges proclama y practica (cf. Pauls 2000: 47-ss). Hacia el final, uno de los fragmentos augura la felicidad a "los que guardan en la memoria palabras de Virgilio o de Cristo, porque éstas darán luz a sus días" (OCII: 390), igualando a Jesús con uno de los epítomes de la poesía occidental. Sin embargo, resulta claro que la imagen sobre la que Borges trabaja en este texto es, ante todo, la del maestro, y lo que está en discusión es la dimensión doctrinaria del discurso de Jesús. En este sentido, la elección del Sermón del Monte como hipotexto es significativa: se trata de un discurso central en la enseñanza de Jesús, en el que los teólogos de distintas denominaciones encuentran los fundamentos de la ética cristiana.

El texto exhibe una consideración crítica y heterodoxa de la doctrina cristiana y, a la vez, un ostensible interés, que lo sitúa claramente como parte del posicionamiento agnóstico que hemos caracterizado anteriormente. El autor implicado por los "Fragmentos..." no es un cristiano creyente sino, en palabras de Almeida, un "sabio desencantado" (2000: 146). En buena medida, 
"Fragmentos..." está construido como una inversión del discurso evangélico, al punto de que el escritor llegó a declarar que el texto era "anticristiano" (Carrizo [1979] 1997:134). Si Jesús comienza las bienaventuranzas afirmando paradójicamente "Bienaventurados los pobres en espíritu...", "Bienaventurados los que lloran..." (Mt 5,3-4, Reina Valera [1909] 2011), Borges proclamará en su texto una lógica más razonable — que, además, pasa de lo colectivo (plural) a lo individual (singular)—: "Desdichado el pobre en espíritu...", "Desdichado el que llora..." (OCII: 389). ${ }^{30}$ Sin embargo, la relación que establece el texto con la ética proclamada por Jesús no puede simplemente reducirse a la crítica y la inversión. Ciertamente, no la acepta como verdad revelada: parodia los dichos de Jesús, los cuestiona o directamente los niega. Pero es indudable que Borges formula su propuesta ética en diálogo con el cristianismo. ${ }^{31}$ El evangelio funciona como hipotexto de los fragmentos borgeanos y como punto de partida que determina los temas sobre los que el escritor dejará sentada su posición. No solo declarativamente sino en su propio trabajo de escritura, Borges parece conferir a las enseñanzas de Jesús una importancia innegable: aún para oponérseles, es necesario volver a ellas.

Para finalizar esta sección, dejemos asentado que lo que más parece haber interesado a Borges del magisterio de Jesús es su "doctrina del perdón”, como la denomina en "Cristo en la Cruz". Su posición al respecto es contradictoria. Tanto en "Fragmentos..." como

\footnotetext{
30 Ignacio Navarro señala su sorpresa ante esta inversión borgeana que traza la vuelta completa y repone la lógica que había invertido el discurso evangélico: "El recurso de Borges en este texto es, en buena medida, invertir los dichos de Jesús: Desdichado el pobre de espíritu..., etc., en vez de Bienaventurados los pobres de espiritu..., etc. Lo que me deja perplejo es que Borges, que parece haber entendido cada página y cada recurso que sostiene y hace eficaz a cada página, no parece advertir que fue ese, precisamente, el 'recurso' usado por Cristo: felices los pobres, los que lloran, los hambrientos, ¡los infelices! Borges, al invertir el texto ya invertido por Jesús, repone una lógica trivial, ordinaria, que es la que Jesús había quebrado con su sorprendente discurso" (Navarro 2009: 372).

31 En el prólogo de 1969 a Elogio de la sombra, el libro donde está incluido este texto, Borges había señalado la aparición de la ética como una nueva preocupación presente en su obra. Cf. sobre este punto Romera (2016).
} 
en "Una oración" —otro hipertexto evangélico incluido en Elogio de la sombra-, parece tomar distancia de la perspectiva evangélica. ${ }^{32}$ Sin embargo, en otros escritos, indaga las potencialidades de esta práctica, y especialmente la posibilidad de que Cristo, al perdonar, sea capaz de redimir el pasado y aligerar la carga de los hombres. ${ }^{33}$ Quizás el máximo ejemplo de esta ambigüedad se encuentre en "Otro fragmento apócrifo" - texto que ya desde su título está en continuidad con "Fragmentos..."-. Allí el Maestro comienza por afirmar "Nadie puede perdonar, ni siquiera el Señor" para concluir asegurando al discípulo arrepentido: "Si algo ha quedado de tu culpa, yo cargaré con ella” (OCIII: 485). La cuestión requeriría un estudio independiente, pero subrayemos aquí la relevancia que la doctrina del perdón tiene para una imagen de Cristo como maestro y la valoración contradictoria que esta "enseñanza” recibe.

\section{El verbo encarnado}

Además de la figura del crucificado, que parece apuntar a una humanización de Jesús y a rescatar el carácter dramático de su sacrificio, y la del poeta y maestro oral, que se concentra en sus palabras y enseñanzas - una valoración superlativa, pero en términos éticos y estéticos, no religiosos-; encontramos también en la obra de Borges una serie de referencias que afirman, de modo más o menos

\footnotetext{
32 En la singular reescritura del Padre Nuestro que constituye "Una oración”, el yo lírico se distancia del pedido "perdona nuestras deudas": "No puedo suplicar que mis errores me sean perdonados; el perdón es un acto ajeno y solo yo puedo salvarme. El perdón purifica al ofendido, no al ofensor, a quien casi no le concierne” (OCII: 392). En "Fragmentos...", varios versículos se refieren a la doctrina del perdón, discutiendo o invirtiendo lo propuesto en el evangelio (cf. 8, 27, 28, 29, OCII: 389-390).

33 En "Cristo en la cruz" se alude a Wilde para afirmar que el perdón cristiano "puede anular el pasado" ( $c f$. OCIII: 453). Esta posibilidad es explorada en el relato "La otra muerte" — significativamente titulado, en su primera versión, "La redención”-, donde un gaucho entrerriano, "por obra de una larga pasión” (OCI: 575) logra modificar la historia (cf. Adur 2012). En "Lucas 23, se citan las palabras con las que Jesús, desde la cruz, perdona al "buen ladrón” ” (OCII: 218). Esas mismas “[...] palabras que en un crepúsculo se dijeron de una cruz a otra cruz", se recuperan también en "Otro poema de los dones" (OCII: 314), como uno de los acontecimientos históricos por los que el poeta da gracias.
} 
explícito, la naturaleza divina de Jesús. Esto no implica, o no necesariamente, un posicionamiento creyente para el escritor, pero sí lleva a examinar las posibilidades —estéticas y filosóficas- de un Dios que se hace hombre. ${ }^{34}$

Tenemos, por un lado, una serie de menciones de Jesús como “dios”, "un dios”, “Dios”, e incluso como "Redentor”, que pueden encontrarse en textos de distintas épocas, pero con mayor frecuencia en la última etapa de la producción borgeana. Por ejemplo, en "La otra muerte" (OCI: 575), “Mutaciones” (OCII: 176), “Paradiso XXXI, 108” (OCII: 178), “Lucas 23” (OCII: 218) o “In memoriam JFK” (OCII: 231). Aunque algunas de ellas pueden considerarse como meramente retóricas, no pueden desdeñarse del todo en tanto contribuyen a complejizar la figura de Cristo que dibuja la obra borgeana, donde las negaciones de su divinidad coexisten con afirmaciones de la misma. Nos interesa detenernos sin embargo en textos donde la condición divina de Jesús no solo se menciona sino que se considera - al menos hipotéticamente- como una premisa de la que se desprende una serie de corolarios.

\subsection{La encarnación como sacrificio}

Un primer desarrollo de la cuestión de la divinidad de Jesús, lo hallamos en una serie de ensayos de los años treinta: "Vindicación de la cábala", "Vindicación del falso Basílides" — ambos recogidos en la primera edición de Discusión, de1932 - e "Historia de la eternidad" - el ensayo que abre el volumen homónimo, de 1936-. ${ }^{35}$

\footnotetext{
34 Retomando la terminología de Maingueneau (2006: 136) podríamos afirmar que el inscritor o sujeto textual de ciertos relatos y poemas acepta la naturaleza divina de Cristo, al menos como premisa para desarrollar especulaciones, poemas o narraciones, pero esto no significa que esa creencia se traduzca en un posicionamiento de escritor. Este último no puede definirse a partir de un texto puntual, sino que implica una compleja dialéctica entre obra, intervenciones públicas, trayectorias intertextuales, vinculaciones con otros actores en el campo literario, etc.

35 Subrayemos que, en estos ensayos, la divinidad de Jesús se presenta como un dogma de la teología cristiana que se examina, pero no como una creencia del inscritor (Maingueneau 2006). Como hemos dicho, es justamente a partir de la década del treinta cuando Borges construye su posicionamiento de escritor agnóstico.
} 
En estos textos, Borges considera a Cristo como la segunda persona de la Trinidad, como "Hijo", en relación con Dios Padre - y, en menor medida, con el Espíritu-. El primer hito que resulta significativo en esta línea es un fragmento de "Vindicación de la cábala":

Entendemos que renunciar a la Trinidad —a la Dualidad, por lo menos-es hacer de Jesús un delegado ocasional del Señor, un incidente de la historia, no el auditor imperecedero, continuo, de nuestra devoción. Si el Hijo no es también el Padre, la redención no es obra directa divina; si no es eterno, tampoco lo será el sacrificio de haberse rebajado a hombre y haber muerto en la cruz (OCI:210) [El destacado es nuestro].

El fragmento se repite, casi literalmente, en "Historia de la eternidad":

Entendemos que renunciar a la Trinidad -a la Dualidad, por lo menos- es hacer de Jesús un delegado ocasional del Señor, un incidente de la historia, no el auditor imperecedero, continuo, de nuestra devoción. Si el Hijo no es también el Padre, la redención no es obra directa divina; si no es eterno, tampoco lo será el sacrificio de haberse denigrado a hombre y haber muerto en la cruz. (OCI: 359) [El destacado es nuestro].

En estos textos, Borges sitúa una cuestión que surge al considerar la divinidad del Hijo. Si Jesús es Dios, antes que morir en la cruz, el verdadero sacrificio fue hacerse hombre: "rebajarse”, “denigrarse" de tal modo, pasar de la perfección a lo imperfecto. El escándalo que implica afirmar que un Dios se ha hecho hombre fue uno de los centros de las polémicas que atravesaron los convulsos primeros tiempos del cristianismo. Justamente a esa cuestión se refiere Borges en el otro ensayo que mencionamos, "Vindicación del falso Basílides”. Lo central en la cosmología gnóstica es la afirmación de la corrupción inherente del mundo material, obra de un demiurgo malvado. Por lo tanto, es impensable que el Redentor divino asuma la corporalidad: "la carne degrada", por lo que el cuerpo de Cristo es un simulacro, una mera apariencia (OCI: 214). Tanto en su exposición de la doctrina ortodoxa — “Vindicación de la Cábala” e 
"Historia de la eternidad" - como en su recuento de heterodoxias — "Vindicación del falso Basílides”- Borges deja claro que, si se acepta la divinidad de Cristo, la encarnación solo puede considerarse como un sacrificio, una degradación; problemática para los cristianos y directamente inadmisible para los gnósticos.

Las hipótesis presentadas en estos ensayos se explorarán también en desarrollos narrativos y líricos, en tres direcciones fundamentales. La primera tiene que ver con considerar la degradación como un sacrificio, aún mayor que la entrega de la propia vida. En este sentido, se trataría de una inversión de lo que Hadis (2006: 414-ss) ha llamado "religión del coraje", que recorre varios textos borgeanos, desde los referidos a gauchos y compadritos hasta las recreaciones de guerreros nórdicos. Frente a estos valientes, para quienes el nombre y la fama valen más que la vida, encontramos al menos dos personajes borgeanos que aceptan la degradación en pos de lo que consideran un bien mayor: Kuranosuké — de "El incivil maestro de ceremonias Kotsuké no Tsuké” — recogido en Historia universal de la infamia - y Emma Zunz — protagonista del cuento homónimo incluido en El Aleph- En un caso, se trata de una conocida tradición oriental, muy alejada del orbe cristiano. En el otro, de un cuento con personajes judíos, que incluye varias referencias que pueden leerse como cristológicas. Pero en ambos, entendemos, se trabaja sobre la noción de abajamiento, en un sentido similar al que se atribuye al Hijo en los ensayos citados.

En "El incivil maestro de ceremonias...", Borges reescribe la historia de los cuarenta y siete ronin, siguiendo — según el mismo declara- la versión de A. B. Mitford. Tras haber sido condenado al suicidio su maestro - el señor de la torre de Ako-, Kuranosuké, consejero y uno de los capitanes de la torre, emprende un singular plan para alcanzar la venganza contra el responsable de esa muerte:

Kotsuké no Suké, el odiado maestro de ceremonias, había fortificado su casa y una nube de arqueros y de esgrimistas custodiaba su palanquín. Contaba con espías incorruptibles puntuales y secretos. A ninguno celaban y vigilaban como al presunto capitán de los vengadores: Kuranosuké, el consejero. Este lo advirtió por azar y 
fundó su proyecto vindicatorio sobre ese dato. [...] Se dejó arrebatar por los lupanares, por las casas de juego y por las tabernas. A pesar de sus canas, se codeó con rameras y con poetas, y hasta con gente peor. Una vez lo expulsaron de una taberna y amaneció dormido en el umbral, la cabeza revolcada en un vómito. [...] Los hechos no pararon ahí. El consejero despidió a su mujer y al menor de sus hijos, y compró una querida en un lupanar, famosa infamia que alegró el corazón y relajó la temerosa prudencia del enemigo. Éste acabó por despachar la mitad de sus guardias (OCI: 321).

Como puede observarse, la degradación, que implica el sacrificio de lo más preciado que tenía un guerrero, el propio honor, es parte de un plan que, una vez alcanzada la venganza, culminará — como en el caso de Jesús - con la muerte (voluntaria) del capitán y de los suyos en un suicidio colectivo, lo que para los samuráis constituía un privilegio. Tras la muerte, se sugiere incluso que los ronin se constituyen en una suerte de deidades: a su tumba concurren "a rezar" hombres y niños (OCI: 323).

Un esquema similar reencontramos en uno de los más famosos relatos borgeanos, "Emma Zunz": la hija se hace objeto de degradación como parte de un plan para alcanzar la venganza —respondiendo a un "mandato" paterno_- Emma se hace violar en un bar del puerto, por el hombre más grosero que encuentra. La experiencia es conceptualizada por el narrador como "sacrificio" (OCI: 566): Emma se ha "rebajado" a prostituta para llevar a cabo su misión. En este caso, como dijimos, es posible leer en el personaje una referencia cristológica, en el nombre que - como el de su padre - remite a "Emmanuel”, uno de los que el Evangelio asigna a Jesús como Dios encarnado, Dios “con nosotros” (cf. Mateo 1, 23, Reina Valera [1909] 2011).

\subsection{Un Redentor atroz}

Una segunda dirección en la que Borges explora la condición humana y divina de Cristo la encontramos en la "fantasía cristológica” (OCI: 483) titulada “Tres versiones de Judas”. Retomando de algún modo las especulaciones gnósticas, Borges atribuye a 
Runenberg —a la "tercera versión" que postula este teólogo- la convicción de que asumir la materia, asumir la humanidad, implica necesariamente corromperse:

Dios, arguye Nils Runeberg, se rebajó a ser hombre para la redención del género humano; cabe conjeturar que fue perfecto el sacrificio obrado por él, no invalidado o atenuado por omisiones. Limitar lo que padeció a la agonía de una tarde en la cruz es blasfematorio. Afirmar que fue hombre y que fue incapaz de pecado encierra contradicción; los atributos de impeccabilitas y de bumanitas no son compatibles. [...] Dios totalmente se hizo hombre hasta la infamia, hombre hasta la reprobación y el abismo. Para salvarnos, pudo elegir cualquiera de los destinos que traman la perpleja red de la historia; pudo ser Alejandro o Pitágoras o Rurik o Jesús; eligió un ínfimo destino: fue Judas (OCI: 517).

Runenberg va más lejos que los gnósticos. Estos habían determinado que, ante la imposibilidad de hacerse carne sin degradarse, Dios asume un cuerpo ilusorio, un "fantasma visual" (TR1: 346). El anacrónico heresiarca sueco, en cambio, afirma que Dios se degradó, no solo en hombre, sino en traidor, en infame. Más allá de la provocación que implica afirmar que Judas fue el verdadero hijo de Dios, podemos pensar que Borges opera aquí un verdadero "extrañamiento teológico" sobre el dogma de la encarnación, restituyendo su carácter escandaloso a lo que se había convertido en una fórmula repetida inconscientemente. ${ }^{36}$ Agreguemos que la posibilidad de que la encarnación implique un Cristo pecador - dado que "los atributos de impeccabilitas y de humanitas no son compatibles"- es sugerida, aunque muy tenuemente, en otros textos borgeanos. Así, en "El evangelio según Marcos”, Espinosa, un personaje de evidentes rasgos cristológicos, tiene un encuentro sexual con la hija del capataz, la noche antes de morir crucificado. Más allá de que esto es un pecado en términos de la ortodoxia cristiana

\footnotetext{
36 Recuperando la noción de los formalistas rusos, Barcellos (2007) propone hablar de un "extrañamiento teológico", cuando los procedimientos de desautomatización operan sobre dogmas religiosos. Hemos desarrollado una lectura de "Tres versiones..." en este sentido (Adur 2010b), del que aquí retomamos solo los puntos fundamentales.
} 
-en tanto se trata de sexo extramatrimonial- lo que importa es que el propio protagonista lo percibe como un acto cuestionable: se promete no divulgarlo y, al día siguiente, teme que el padre le pida cuentas de lo sucedido (OCII: 447). En "Otro fragmento apócrifo”, el "Maestro" afirma que "no es de hombres no pecar" y declara que él mismo ha pecado al haber engendrado un hombre, tiempo atrás en Samaría (OCIII: 485) — nuevamente, lo que interesa aquí es que el propio personaje considera esto como pecado-.

Como podrá observarse, tanto los “pecados” como las prácticas (percibidas como) humillantes y/o pecaminosas a las que se someten los personajes, se vinculan directamente con el cuerpo, con la materialidad de lo corporal: la violación de Emma; el yacer en lupanares, rodeado de vómito, del samurái; las relaciones sexuales de Espinosa y “el Maestro”. Quizás puede leerse en este sentido un eco de la convicción gnóstica de que "la carne degrada”. Anotemos, por último, que en ningún caso la degradación, ni siquiera el pecado, conspiran contra la "misión" de los personajes - contra el "plan redentor", si se quiere- Hemos visto que en Emma y Kuranosuké, la misma es parte del plan; en "Otro fragmento apócrifo”, tras declararse a sí mismo pecador, el Maestro asegura a su discípulo: "Si algo ha quedado de tu culpa, yo cargaré con ella" (OCIII: 485).

\subsection{La palabra capaz de decir la totalidad}

Las dos series de textos que comentamos exploran centralmente lo que podríamos llamar la dimensión ética — aunque con implicancias ontológicas - de la concepción de Jesús como Dios hecho hombre: alguien superior - o perfecto - que accede, voluntariamente, a rebajarse, en función de un objetivo ulterior, y las consecuencias que tiene este movimiento descendente. Pero la imagen del Verbo encarnado es también objeto, en la literatura borgeana, de una consideración de orden más filosófico. En efecto, si como se afirma en “Tres versiones...", "El Verbo, cuando fue hecho carne, pasó de la ubicuidad al espacio, de la eternidad a la historia” (OCI: 515), 
lo que está en cuestión es la posibilidad de que lo eterno entre en el tiempo, de que lo simultáneo se manifieste en lo sucesivo. Se trata, sin duda, de una cuestión que es articuladora de una parte significativa de la producción del autor (cf. Navarro 2015): ¿es posible que el lenguaje, que es sucesión, recoja algo de la experiencia de lo simultáneo o, incluso, de lo eterno? ¿Existe una palabra capaz de decir, ella sola, la totalidad de lo real? Esas preguntas, que la encarnación de un Dios pone en escena, resuenan en numerosos relatos y poemas borgeanos, donde lo que moviliza a los personajes - o al yo lírico- es la búsqueda de una palabra — de un Verbo- capaz de recoger algún tipo de totalidad: la de las experiencias místicoepifánicas - "El aleph", "Mateo XXV, 30" -, la de una existencia - "Undr", "El otro tigre"-, la de un espacio — "Parábola de palacio"-, la de un acontecimiento - "El espejo y la máscara”Pero es quizás en "La escritura del Dios" donde la pregunta por una palabra capaz de decirlo todo se plantea con mayor lucidez:

¿Qué tipo de sentencia (me pregunté) construirá una mente absoluta? Consideré que aun en los lenguajes humanos no hay proposición que no implique el universo entero; decir el tigre es decir los tigres que lo engendraron, los ciervos y tortugas que devoró, el pasto de que se alimentaron los ciervos, la tierra que fue madre del pasto, el cielo que dio luz a la tierra. Consideré que en el lenguaje de un dios toda palabra enunciaría esa infinita concatenación de los hechos, y no de un modo implícito, sino explícito, y no de un modo progresivo, sino inmediato. Con el tiempo, la noción de una sentencia divina parecióme pueril o blasfematoria. Un dios, reflexioné, sólo debe decir una palabra, y en esa palabra la plenitud. Ninguna voz articulada por él puede ser inferior al universo o menos que la suma del tiempo. Sombras o simulacros de esa voz que equivale a un lenguaje y a cuanto puede comprender un lenguaje son las ambiciosas y pobres voces humanas, todo, mundo, universo (OCI: 597-598).

El párrafo que citamos es conceptualizado por el propio narrador como el pasaje de un enigma concreto — ¿ cuál es la sentencia secreta que dejó escrita el dios para proteger sus elegidos?- al enigma genérico: ¿cómo sería el lenguaje de un dios? Un lenguaje capaz de decir el infinito, no de un modo implícito, vago, general, sino 
explícito, minucioso, y de forma simultánea, inmediata. ${ }^{37}$ Tal parece ser la búsqueda - estética - que sustenta, como dijimos, buena parte de la producción borgeana ( $c f$. en este sentido las lecturas del relato que proponen Massuh 1980 y Navarro 2009).

Pese a ser atribuida a un sacerdote maya, la pregunta por una palabra divina tiene evidentes vínculos, como anticipamos, con el problema de la encarnación cristiana. Borges, de hecho, confesará en el epílogo de El Aleph haberse visto obligado a poner, "en boca de un mago de la pirámide de Qaholom", argumentos de teólogo (OCI: 629). Recordemos que la fórmula con la que el prólogo del Evangelio de Juan presenta a Cristo es, justamente, como la Palabra -o el Verbo- que lo contiene todo, aquella por la que todo fue hecho (cf. Juan 1, 1-4, Reina Valera [1909] 2011). Esta relación entre lenguaje divino y lenguaje humano se identificará explícitamente con la figura de Jesús como Verbo encarnado, en el poema que abre Elogio de la sombra, titulado "Juan 1, 14", en el que nos detendremos a continuación.

\subsubsection{Condescender al lenguaje}

Desde el título —que Borges había empleado también para un soneto sobre Cristo, publicado en El otro, el mismo (1964)- lo que está en cuestión en "Juan 1,14" es la forma en que el Verbo divino ingresa en el tiempo, en la historia. En efecto, el versículo referido, constituye una de las más antiguas y contundentes afirmaciones de la encarnación de Cristo: "Y aquel Verbo fue hecho carne y habitó entre nosotros [...] lleno de gracia y de verdad" (Reina Valera [1909] 2011). Los primeros versos sitúan la escritura del poema en relación de igualdad con la (Sagrada) Escritura, subrayando su carácter misterioso, como el de toda palabra divina. ${ }^{38}$ Los siguientes, plantean explícitamente la relación entre encarnación y lenguaje:

\footnotetext{
37 Recuérdese el contraste que se propone en “Deutsches Requiem”, entre Walt Withman y el apócrifo poeta David Jerusalem — cuyos nombres no dejan de ser una referencia cristológica-: "Whitman celebra el universo de un modo previo, general, casi indiferente; Jerusalem se alegra de cada cosa, con minucioso amor" (OCI: 578).

38 "No será menos un enigma esta hoja / que la de Mis libros sagrados [...]". Borges, en los seis primeros versos, parece estar aludiendo a la famosa sentencia paulina de 1
} 
Yo que soy el Es, el Fue y el Será, vuelvo a condescender al lenguaje, que es tiempo sucesivo y emblema (OCII: 355).

El descenso desde la eternidad hacia el "tiempo sucesivo" es asumido por la divinidad, en la persona de Jesús, de forma voluntaria, condescendiente. ${ }^{39}$ Asumir el lenguaje humano significa para Dios un "abajarse" complementario del que ya hemos discutido en el terreno ético —e, incluso, podríamos decir, en el ontológico-. El carácter sucesivo del lenguaje, que se corresponde con el carácter temporal de la existencia humana, es - como queda claro en "El Aleph" y en “Mateo 25,30”- un límite. Nuestro lenguaje es inhábil para captar la simultaneidad de la experiencia, lo que —como hemos visto en el apartado anterior - es el punto de partida de la búsqueda de un lenguaje o una palabra total en varios textos de Borges. Lo que se sugiere en este poema es que el lenguaje no es solo "tiempo sucesivo" sino que también es —o puede ser- “emblema”. Es decir, de algún modo, es capaz de cifrar, de representar de forma simbólica, aun aquello que no puede decir cabalmente.

Al discutir la imagen del crucificado, ya hemos visto el recurso que consiste en "presentar un momento como cifra de una vida" (OCIII: 213), y señalamos que era parte constitutiva de la poética borgeana. En "Juan 1, 14”, encontramos otro recurso, que Borges también emplea profusamente para procurar recoger “algo” de la

Corintios 13, 13: "Ahora vemos por espejo, en oscuridad; mas entonces veremos cara a cara [...]” (Reina Valera [1909] 2011). Recordemos que esta afirmación ya había sido objeto de un ensayo, "El espejo de los enigmas" (1940) donde se interpretaba estas palabras no solo en relación a nuestro imperfecto conocimiento de Dios sino "a nuestra visión general” (OCII: 98). Resulta significativo que un poema que se referirá in extenso a la percepción (humana) se abre declarando que esta es imperfecta, oscura, enigmática, en contraste con el conocimiento absoluto atribuible a Dios.

39 Vélez (2008: 206) propone que esta “condescendencia” que implica la encarnación, refleja y redime la caída involuntaria en el tiempo que Borges atribuye a Adán. En efecto, el primer hombre aparece en varios poemas tardíos de Borges, representado como quien ha perdido la eternidad — simbolizada por el jardín del Edén-y entrado en el mundo temporal, con todos los sufrimientos que este implica. Cristo realiza ese descenso por su propia voluntad, y allí radica su heroísmo. La hipótesis de Vélez puede vincularse con lo que hemos dicho antes acerca de la encarnación como sacrificio. 
simultaneidad en la sucesión — como se afirma en "El Aleph” (OCI: 625)_, de la infinitud en lo finito: lo que se ha dado en llamar “enumeración caótica” (Spitzer 1945). La acumulación de elementos aparentemente azarosos, pero cuidadosamente escogidos, permite aludir a una totalidad literalmente inabarcable; su superposición sin nexos - o con nexos que se repiten anafóricamente como "Vi" o "Conocí" - sugieren además la simultaneidad.

Para dar cuenta de la vida terrenal de Jesús, recapitulada sup specie aeternitatis, Borges recurrirá entonces a una estrategia similar a la que encontramos en "El Aleph" y en "Mateo 25,30". ${ }^{40}$ Aunque no tenemos aquí estrictamente una única enumeración - hay varias oraciones separadas por puntos-, se nos presenta una serie de elementos heterogéneos, encabezados - con pocas excepciones- por la repetición anafórica de "Conocí”. ${ }^{41}$

Los versos evocativos incluyen numerosas reminiscencias evangélicas, no solo a episodios centrales como la concepción virginal - "por obra de una magia nací curiosamente de un vientre", cf. Mt 1, 18-20, 24 y Lc 1, 35 y 2,7 (Reina Valera [1909] 2011) - o la crucifixión - “(...) pendí de una cruz”, cf. Mt 27 y sus paralelos (Reina Valera [1909] 2011)—, sino también a cuestiones más circunstanciales, como el tacto de la arena - ya hemos visto que el episodio de la escritura en la arena fascinaba a Borges-, el agua que sacia la sed -alusión al encuentro con la samaritana frente al pozo de Jacob (Jn 4, 6-ss) —, incluso la mención de Galilea y de la carpintería. Es decir, el recuento de esa existencia permite identificarla

40 Entendemos que, dado que la recapitulación de la vida de Jesús se realiza "Desde [Su] eternidad" (OCII: 355), el problema al que se enfrenta el yo lírico es similar al que enfrentaba en "Mateo 25, 30" o en "El Aleph". En efecto, contemplada desde la eternidad divina, la vida humana de Jesús — cualquier vida humana - se percibe como una totalidad simultánea, de la que se debe dar cuenta con el lenguaje sucesivo.

41 "Conocí" parece remitir al "Vi" de "El Aleph", estableciendo no obstante una diferencia. Cervera Salinas (2011:106) ha llamado la atención sobre la elección de un verbo típicamente gnóstico (conocer) para un poema donde lo central es la encarnación de Cristo y su percepción de lo sensible. Agreguemos que "conocer" -así como el "ver lo que nunca se había visto", de uno de los versos- implica que, en su encarnación, Dios aprendió, y por ende, que había cosas que ignoraba. Esto pone en cuestión la omnisciencia y la inmutabilidad divinas, tradicionalmente afirmadas por la teología cristiana. 
claramente con la atribuida por los evangelios a Jesús de Nazaret. Sin embargo, la enumeración no se ciñe estrictamente a elementos reconocibles en el evangelio, sino que el yo lírico evoca otros que parecen más bien universales, en el sentido de ser parte de la experiencia de casi cualquier hombre. Tanto sensaciones, facultades y emociones de un orden intelectual o "espiritual” - la memoria, la razón, la esperanza, el temor, el sueño, la amistad, la amargura-, como otras que remiten a la percepción sensorial del mundo físico: la contemplación de las estrellas, el sabor de la miel, el tacto del metal, el olor de la lluvia, el grito de los pájaros. ${ }^{42}$ Es notable, en contraste con estas evocaciones, la absoluta ausencia de alusiones a los milagros y la resurrección. Aunque se trata de un poema que presupone la divinidad de Cristo, el énfasis en la enumeración está puesto en la bumanidad de Jesús, en aquellas experiencias que subrayan su carnalidad y aquellas que parecen acercarlo al resto de los hombres — con la excepción, claro está, de la crucifixión-.

Para finalizar, queremos detenernos brevemente en un último punto. ¿Quién habla en este poema? "Juan 1, 14” construye una instancia de enunciación compleja. Romera (2012: 148) ha señalado que el texto tiene tres niveles de enunciación que corresponderían al Padre, el Hijo y el Espíritu Santo. En efecto, el Padre parece asumir la voz en los primeros versos, como lo indica el hecho de que se refiera a "Mis hijos", "Mis libros sagrados" (OCII: 35) y que se defina "Yo que soy el Es, el Fue y el Será” - lo que remite al nombre divino revelado a Moisés en Éxodo 3,14, aunque también a Apocalipsis 22, 3- La voz se desplaza luego a la encarnación humana del Hijo, quien afirma "nací curiosamente de un vientre”, para después, como ya vimos, recapitular poéticamente su experiencia en el mundo. Pero el mismo enunciador, al proclamarse como inspirador de esta enigmática escritura sagrada, se atribuye una de las funciones propias del Espíritu, según el propio Borges recuerda en "Una vindicación de la Cábala” (OCI: 209). Quizás más que de tres niveles

42 La presencia de imágenes sensoriales en este poema ha sido señalada por Cervera Salinas (2011) y Romera (2012). Recordemos también aquí que la preponderancia de lo concreto era un rasgo que Borges atribuía a Jesús en tanto poeta. 
de enunciación, podríamos hablar de un enunciador "trinitario", en tanto las voces parecen solaparse y superponerse, de modo tal que el poeta pareciera jugar con la identidad que la teología atribuye al Padre, al Hijo y al Espíritu - tres personas distintas, un solo Dios, según la fórmula canónica-. Se podría sumar incluso otro componente de esta instancia enunciativa, el "amanuense”, el "hombre cualquiera", al que la escritura le ha sido encomendada, que podría identificarse con el escritor. Este sería un último avatar de la "encarnación" discursiva, de la "condescendencia al lenguaje": Dios - como Borges, ciego al momento de componer este poemasolo puede dictar, a un amanuense que es quien, materialmente, se encarga de escribir sus palabras.

\section{Conclusión}

"Los pedazos —dijo—. No se pueden juntar" Saer ([1969] 2006: 91)

Hemos trazado un recorrido por las principales imágenes de Jesús que se encuentran en la obra de Borges. El crucificado, la más recurrente, se caracteriza por poner de relieve los rasgos humanos de Jesús, su condición mortal —negando o difuminando los sobrenaturales, como los milagros y la resurrección- y el dramatismo de la entrega de su vida, que es valorada tanto en términos éticos como estéticos - por la dignidad con la que enfrenta la muerte y por lo memorable de la "escena", con sus diálogos y gestos-. La segunda imagen en la que nos detuvimos es en la de Jesús como orador, maestro o poeta, según se considere su discurso en clave estética — sus parábolas, la novedad de sus metáforas- o ética — su doctrina del perdón, y en general lo proclamado en el Sermón del monte, así sea para discutirlo- Se trata de una imagen que está en continuidad con la anterior - como se observa en "El evangelio según Marcos" o en "Cristo en la cruz" - en tanto, si bien ponen el foco en distintos aspectos del personaje, en ambos casos Jesús es considerado desde una perspectiva no religiosa, como una figura histórica de un relieve indiscutible, pero humana. La tercera de las imágenes que abordamos, 
la del Verbo encarnado, implica una ruptura en este sentido: Jesús es presentado como Dios hecho hombre, lo que necesariamente introduce un componente sobrenatural, si bien, como destacamos, la divinidad de Cristo aparece más como un presupuesto sobre el que se proponen desarrollos literarios - poéticos, narrativos o ensayísticos-, que como un artículo de fe religiosa. Las referencias a milagros y a la resurrección siguen completamente ausentes.

Hemos propuesto además que estas distintas imágenes de Cristo pueden vincularse con núcleos de la poética borgeana. Así, la crucifixión aparece como una suerte de sinécdoque de la vida entera de Jesús, en lo que constituye un ejemplo privilegiado - si no directamente un modelo- del recurso característicamente borgeano de definir un personaje a partir de un episodio que condensa toda su vida. Con respecto a la imagen de Jesús como poeta, señalamos que Borges lo sitúa en contraste con el discurso teológico, como parte de un posicionamiento central de su estética que consiste en la valoración de lo concreto por sobre lo abstracto, como objeto propio de la literatura. Por último, hemos visto que la imagen del Verbo encarnado puede vincularse con un núcleo de la obra borgeana: la posibilidad de expresar lo infinito en lo finito, lo simultáneo en lo sucesivo, a través de la palabra poética.

Para finalizar, subrayemos que nos hemos concentrado aquí solo en tres imágenes principales y articuladoras, aquellas que el escritor despliega más consistentemente a lo largo de su obra. El trabajo podría multiplicarse si consideráramos también aquellas que Borges retoma de otros autores - para comentarlas, discutirlas o simplemente citarlas: el Jesús de Quevedo, el de Klemm, el de Milton, el de Donne, el de Almafuerte, el de Dante... Se ha señalado repetidamente que cada época imagina su propia versión de Jesucristo. Borges no solo parece haber contribuido a forjar la correspondiente al siglo XX - al punto de que ya es posible hablar, entre la "infinidad de versiones de Jesús de Nazareth", de un "Jesús borgeano" (Falú 2014: 124)— sino que también ha dispersado, a lo largo de su obra, una parte de la pluralidad de las formas en que los hombres han imaginado a Cristo. 
Las diferentes imágenes que propone el escritor, más allá de las continuidades que pueden establecerse entre ellas, no llegan a conformar un todo coherente. Aparecen más bien como distintas facetas de un diamante. Compuesto por todas estas imágenes, y muchas más, Jesucristo, el poeta, el judío, el maestro, el pecador, el guerrero, el hombre, el dios, el moribundo, refulge en su complejidad como uno de los centros secretos de la obra de Borges.

\section{Referencias bibliográficas}

ADUR, Lucas

2010a "El hombre más extraordinario que recuerda la historia. Borges y Vida de Jesús de Ernest Renan”. En Borges en Francia. Ed., Magdalena Cámpora y Javier González. Buenos Aires: Educa. $2010 \mathrm{~b}$ "Un atroz redentor. El Cristo de las 'Tres versiones de Judas"”. Ponencia presentada en las X Jornadas "Borges y los otros". Buenos Aires, Fundación Internacional Jorge Luis Borges.

2012 "Escándalos de la razón. Nivelación y desajustes de la literatura y la teología en La otra muerte de J.L. Borges”. Revista Teoliteraria. 3, 124-142. https://doi.org/10.19143/2236-9937. 2012v2n3p124-142

2014 Borges y el cristianismo. Posiciones, diálogos y polémicas. Tesis doctoral. Buenos Aires: Universidad de Buenos Aires.

2016a “Las biblias de Borges". Variaciones Borges. 41, 3-25.

$2016 b$ "Reescrituras bíblicas en la obra de J.L. Borges. 'Tema del traidor y del héroe' y los cuentos de sacrificio”. Letral. 17, 26-40.

Agamben, Giorgio

2009 Profanaciones. Buenos Aires: Adriana Hidalgo

Almeida, Iván

2000 “Felices los felices». Las bienaventuranzas según Borges”. En Borges en Bruselas. Ed., Robin Lefere. Madrid: Visor, 143-159.

Barcellos, José Carlos

2007 "A terceira margem da ficção: literatura e teologia em Jorge Luis Borges”. En Actas del I Coloquio Latinoamericano de Literatura y Teología. Buenos Aires: ALALITE. Cd-rom. 
BORGES, Jorge Luis

1996a Obras completas I. Buenos Aires: Emecé. [OCI]

1996b Obras completas II. Buenos Aires: Emecé. [OCII]

1996c Obras completas III. Buenos Aires: Emecé. [OCIII]

1997 Textos recobrados. 1919-1929. Buenos Aires: Emecé. [TR1].

[1928]1998 El idioma de los argentinos. Madrid: Alianza

1999 Borges en Sur. Buenos Aires: Emecé.

2000a Arte poética. Barcelona: Crítica.

2000b Borges profesor. Eds., Martín Arias y Martín Hadis. Buenos Aires: Emecé.

2001 Textos recobrados. 1931-1955. Buenos Aires: Emecé. [TR2]

2003 Textos recobrados 1956-1986. Buenos Aires: Emecé. [TR3]

2005 Obras completas IV. Buenos Aires: Emecé. [OCIV]

Borges Jorge Luis y Betina EDELBERG

[1955]1998 Leopoldo Lugones. Buenos Aires: Emecé.

BOrges, Jorge Luis y Alicia JuRAdo

[1976] 1991 ¿Qué es el budismo? Buenos Aires: Emecé.

Borges, Jorge Luis y María Kodama

1978 Breve antología anglosajona. Santiago de Chile: Ediciones La Ciudad.

BORGES, Jorge Luis y María Esther VÁzQUEZ

[1965] 1997 Introducción a la literatura inglesa. Buenos Aires: Emecé.

[1965] 1998 Literaturas germánicas medievales. Buenos Aires: Alianza.

Carrizo, Antonio

[1979] 1997 Borges el memorioso. Conversaciones de Jorge Luis Borges con Antonio Carrizo. México: FCE.

Castillo, Abelardo

1961 El otro Judas. Buenos Aires: Ed. El Escarabajo de Oro.

1999 El evangelio según Van Hutten. Buenos Aires: Seix Barral.

Cervera Salinas, Vicente

2011 "El universo sensitivo del verbo poético. Borges y el 'olor de la carpintería”". Cartaphilus. Revista de investigación y crítica estética. 9, 98-110.

D’Angelo, Biaggio

2005 Borges en el centro del infinito. Lima: Universidad Católica Sedes Sapientiae. 
Denevi, Marco

1966 Falsificaciones. Buenos Aires: Eudeba.

FALú, Darío

2014 "El escritor inútil". En El hombre que atrapaba mujeres. Buenos Aires: Prosa, 115-125.

FERrari, Osvaldo

1999 Reencuentro. Diálogos inéditos con Borges. Buenos Aires: Sudamericana.

FLynN, Annete

2009 The Quest of God in the Work of Borges. Londres: Continuum.

FRESÁn, Rodrigo

1993 Vidas de santos. Buenos Aires: Planeta.

FRESKO, Susana

2002 Quel "vano cerbero teologico": lidea di Dio in Jorge Luis Borges. Consultado: 10 de octubre de 2016. < http://www. borges.pitt.edu/bsol/pdf/fresko.pdf >

GenETTE, Gerard

1989 Palimpsestos. La literatura en segundo grado. Madrid: Aguilar.

HADIS, Martín

2006 Literatos y excéntricos. Buenos Aires: Sudamericana.

Kodama, María

1996 "Jorge Luis Borges y la experiencia mística”. En El sol a medianoche. La experiencia mistica: tradición y actualidad. Eds., Luce López-Baralt y Lorenzo Piera. Madrid: Trotta, 77-84.

LEFERE, Robin

1998 Borges y los poderes de la literatura. Bern: Peter Lang.

Magnavacca, Silvia

2009 Filósofos medievales en la obra de Borges. Buenos Aires: Miño y Dávila.

Maingueneau, Dominique

2006 Discurso Literario. San Pablo: Contexto.

Massuh, Gabriela

1980 Borges: una estética del silencio. Buenos Aires: Editorial de Belgrano. 
Milleret, Jean

1970 Entrevistas con Jorge Luis Borges. Caracas: Monte Ávila.

Muñoz Rengel, Juan Jacinto

2000 “En qué creía Borges?”. Iberoromania. 51, 91-104.

NAHSON, Daniel

2009 "Dios, Cristo, Borges y el canon de los evangelios". En La crítica del mito. Borges y la literatura como sueño de vida. Madrid: Vervuert/Iberoamericana, 159-227.

NAVArRo, Ignacio

2009 Últimas inquisiciones. Borges y Von Balthasar recíprocos. Buenos Aires: Ágape/Bonum.

2015 "La pregunta detrás de la obra”. Revista Teología. 52, 116, 123-133.

Pauls, Alan 2000 El factor Borges. Buenos Aires: Fondo de Cultura Económica.

Reina VAlera

[1909]2011 La Santa Biblia. Antiguo y nuevo testamento. Antigua versión de Casiodoro de Reina (1569), revisada por Cipriano de Valera (1602). Corea: Sociedades Bíblicas Unidas.

RENAN, Ernest

[1863]2003 Vida de Jesús. Madrid: Edaf.

Romera, María Lucrecia

2012 "Jorge Luis Borges: poesía y evangelio". En La fe en el universo literario de Jorge Luis Borges. Eds., Ruth Fine y Daniel Blaustein. Hildesheim: Georg Olms Verlag, 145-175.

2016 "Fragmentos de un evangelio apócrifo, de J.L. Borges: un legado ético de la poesía”. Ponencia presentada en el XIX Congreso Internacional de Hispanistas, Universidad de Münster, Alemania.

SAER, Juan José

[1969]2006 Cicatrices. Buenos Aires: Seix Barral.

SARLO, Beatriz

2003 Borges, un escritor en las orillas. Buenos Aires: Seix Barral.

Soldani, Aníbal

1994 El credo agnóstico de Borges. Buenos Aires: Erregé. 
Adur • Un dios despedazado y disperso. Imágenes de Jesús en la obra de Borges 367

SPITZER, Leo

1945 La enumeración caótica en la poesía moderna. Buenos Aires: Facultad de Filosofía y Letras.

SUCRE, Guillermo

1968 Borges, el poeta. Caracas: Monte Ávila

VÁzQuez, María Esther

1977 Borges: imágenes, memorias y diálogos. Caracas: Monte Ávila.

VéLEz, Gonzalo Salvador

2008 Borges y la Biblia. Presencia de la Biblia en la obra de Jorge Luis Borges. Tesis doctoral. Barcelona: Pompeu Frabra. Consultado: 20 de octubre de 2016. <http://www.tdx.cat/ handle/10803/7447>.

WiTTGENSTEIN, Ludwig

2003 Tractatus logico-philosopicus. Madrid: Alianza

Zagal Arreguín, Héctor

1999 "El cristianismo de Borges”. En Ocho ensayos sobre Borges. México: Publicaciones Cruz, 179-198.

Ziolkowski, Theodor

1982 La vida de Jesús en la ficción literaria. Caracas: Monte Ávila.

Recepción: 13/12/2016 Aceptación: 03/10/2017 